The opinion in the Hurn case should, very definitely, mark the opening of a new era in the settlement of multiple question proceedings. The rule enunciated, if intelligently applied by the lower federal courts, should go far to remedy the chaos previously existing in this difficult field.

MERWIN S. ROSENBERG

\title{
DISCHARGE IN BANKRUPTCY AND THE ASSIGNMENT OF FUTURE WAGES
}

May a creditor who holds an assignment of the future earnings of his debtor under an existing contract of employment enforce that assignment as the wages accrue, even after the debtor has been discharged in bankruptcy? This question has become one of great importance during the present period of depression, ${ }^{x}$ but there has been a sharp difference of opinion among the courts as to the correct answer:

The courts have usually analyzed the problem by inquiring as to the existence of a "lien." Analogous problems have arisen in connection with the

cases (see 28 U.S.C. $\S_{4} \mathrm{I}(\mathrm{I}$ ), note $9 \mathrm{r} \mathrm{I}$ and following), and the language in the "infringement" cases can be construed as an adaptation of that jurisdictional concept to a new use. On the other hand, it seems probable that this class of case was invented by the lower federal courts to evade the effect of Supreme Court decisions prior to the Hurn case, in such instances as the merits of the case appealed strongly to the court. If so, the same result can now be reached by following the language of the Hurn case, without speaking of "aggravating damage."

I For a careful study of the wage assignment question in Chicago, in recent years, see Fortas, Wage Assignments in Chicago-State Street Furniture Co. v. Armour \& Co., 42 Yale L. Jour. 536 (1933).

${ }^{2}$ In re West, I 28 Fed. 205 , rr Am. B.R. 782 (D.C. Ore. I904); In re Karns, 148 Fed. I43, I6 Am. B.R. 84 I (D.C.S.D. Ohio I905); In re Home Discount Co., 147 Fed. 538, Am. B.R. 168 (D.C.N.D. Ala. I906); In re Ludeke, 17I Fed. 292, 22 Am. B.R. 267 (D.C.E.D.N.Y. I909); In re Lineberry, I83 Fed. 338, 25 Am. B.R. I64 (D.C.N.D. Ala. I910); In re Gillespie, 209 Fed. I003, 32 Am. B.R. 434 (D.C.E.D.N.Y. xgr3); In re Green, 213 Fed. 542, 32 Am. B.R. 433 (D.C.E.D.N.Y. I9 4 4); In re Voorhees, 4I F. (2d) 8I, I5 Am. B.R. (N.S.) 666 (D.C.N.D. Ohio I930); In re Fellows, 43 F. (2d) I22, I6 Am. B.R. (N.S.) 355 (D.C. Okla. I930); Seaboard Small Loan Co. v. Ottinger, 50 F. (2d). 856, 18 Am. B.R. (N.S.) 500 (C.C.A. $4^{\text {th }} 193$ r); In re Potts, 54 F. (2d) I44, I8 Am. B.R. (N.S.) 436 (D.C. Idaho I93I); Levi v. Loevenhart, I 38 Ky. I33, I27 S.W. 748, I37 Am. St. Rep. 377, 30 L.R.A. (N.S.) 375 (I9ro); Leitch v. No. Pac. Ry. Co., 95 Minn. 35, 103 N.W. 704 (1905); Rate v. Amer. Smelting \& Ref. Co., 56 Mont. 277, I84 Pac. 478 (I9I9); Hupp v. Union Pac. R. Co., 99 Neb. 654, I57 N.W. 343 (Igr6); Public Finance Co. v. Rowe, I23 Ohio St. 206, I 74 N.E. 738 (I93I). All of the above cases held that no lien existed. The following held that there was a lien: Mallin v. Wenham, 209 IIl. 252, 70 N.E. 564, 65 L.R.A. 602 (1904); Monarch Discount Co. v. C. \& O. R. R. Co., 285 Ill. 233,120 N.E. 743 (rgr8); Dumont, Roberts \& Co. v. McDougall, 200 Ill. App. 583 (rgr6); Citizens Loan Assn. v. B. \& M. R. R. Co., I96 Mass. 528, 82 N.E. 696 (1907); Raulines v. Levi, 232 Mass. 42, I2I N.E. 500 (Igrg); and perhaps Leslie v. Roberts, 32 S.W. (2d) 873 (Tex. Civ. App. 1930). 
assignment of future crops on the assignor's land; ${ }^{3}$ the assignment of an expectancy -an estate which the assignor has a mere possibility of acquiring by will or inheritance; 4 the assignment of future book accounts; $;$ and other similar transactions. The federal district and appellate courts are in almost unanimous accord that the wage assignments are not enforceable after bankruptcy, but the state courts are divided with a strong minority view held in Illinois and Massachusetts particularly favoring enforcement. The other types of cases, arising in the state courts, reveal the same dispute with the tendency being to allow enforcement.

This dispute presents the fundamental question as to whether or not the equitable right conferred by such an assignment of future property is a right in rem or only in personam. Mr. Justice Story said that the assignee of future property "has not, strictly speaking, a jus ad rem, any more than a jus in re. It is not an interest in the property, but a mere right under the contract." 6 Professor Pomeroy, however, concluded that the assignee's right was an "equitable ownership of property in abeyance, .... . which finally changed into an absolute property upon the happening of a future event." 7 He also calls the transaction an "assignment of the present possibility."

The courts generally have not examined this issue, but most of those denying the existence of a right surviving bankruptcy have stressed the impossibility of owning a thing not yet in existence. They adopt the theory that equity for the purpose of effecting justice treats the purported present assignment as a contract to assign, the lien coming into existence as soon as the assignor becomes the actual owner of the property.9

The courts reaching the opposite conclusion usually assume that a lien comes into existence immediately upon the execution of the assignment, ${ }^{\mathrm{I0}}$ or else rest upon the authority of Professor Pomeroy. ${ }^{x x}$ Another view is that of the Eng-

3 No lien existed: Butler Cotton Oil Co. v. Collins, 200 Ala. 217, 75 So. 795 (I9I7). Lien did exist: Thompson Yards v. Richardson, 5I N.D. 24I, r99 N.W. 863 (r924); Union Nat. Bank of Minot v. Lenton, 54 N.D. 262, 209 N.W. $35^{\circ}$ (1926); Waters v. B. F. Ellington \& Co., 289 S.IW. 4I7 (Tex. Civ. App. I926).

4 No lien existed: Gannon v. Graham, 2 II Ia. 5I6, 23I N.W. 675 (1930). Lien did exist; Bridge v. Kedon, I63 Cal. 493, I26 Pac. I49 (Igr2). See also, In re Lind, [rgr5] I Ch. 744, [1915] 2 Ch. 344, 8 Br. Rul. Cas. 242.

5 Taylor v. Barton-Child Co., 228 Mass. I26, II 7 N.E. 43 (IgI8) is sometimes cited as applicable here, but is readily distinguishable on its facts.

${ }^{6} 2$ Story, Eq. Jur., \$ I040c.

${ }^{7} 3$ Pomeroy, Eq. Jur. (3rd ed. r905), § I27r.

${ }^{8}$ Ibid., $\S$ 1 288 . See also authorities cited in Taylor v. Swafford, I22 Tenn. 303, r23 S.W. $35 \circ$ (I 1909 ); and on the related problem of the nature of the right of a cestui que trust, the il-

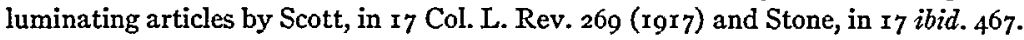

- See particularly, In re West, In re Home Discount Co., and Seaboard Small Loan Co. v. Ottinger, supra, note 2; and Gannon v. Graham, supra, note 4 . rely.

${ }^{\text {Io }}$ See particularly, Mallin v. Wenham, supra, note 2, upon which most of the later decisions

"See Bridge v. Kedon, supra, note 4, a leading case. 
lish case, In re Lind, ${ }^{\mathrm{I2}}$ in which the court found an equitable charge. The court emphasized particularly the intent and understanding of the parties that a right of security against the property itself was being conferred upon the assignee. The "potentiality doctrine" is sometimes invoked to show that something exists to which a lien may presently attach. ${ }^{\mathrm{x}}$ This theory, however, if defensible at all, would seem applicable only to such cases as those of wage and crop assignments, and not to those of bare possibilities, such as expectancies and future book accounts. This distinction, however, is expressly repudiated in one of the leading cases on the question. $\mathbf{x}^{4}$.

If the view be taken, however, that no lien exists, but only a personal contract of assignment, it becomes difficult to explain why the obligation of that contract, since it was not itself provable under the Act or merged in the debt at the time of bankruptcy, ${ }^{x}$ should be held barred by the discharge along with the debt. It might well be regarded as an independent contract, simply originating from the debtor-creditor relationship and not otherwise connected with the debt. Here again the courts merely state the conclusion that the debt and the assignment are so closely bound together that when the debt becomes unenforceable, the collateral contract must fall with it. ${ }^{16}$ The same conclusion appears in a considerable number of cases (though probably a minority) in which it was sought to claim a mortgage on after acquired property when the statute of limitations has run against the debt. It is to be noted that the Illinois courts hold strongly to this opinion. ${ }^{17}$

Professor Williston asserts the theory that an assignment gives the assignee "authority or power to collect and an implied agreement on the assignor's part not to revoke this power," which is not discharged by bankruptcy. ${ }^{18}$ It is his belief that the hardship to the wage earner has been the deciding factor in the cases which refuse to recognize a lien on future wages. That explanation probably would account for the difference found by some writers in the attitude of the state courts toward the assignments of future earnings and toward the assignments of expectancies, future crops, et cetera. ${ }^{x 9}$ On the other hand, it has been pointed out that the refusal to recognize a lien on future earnings would practically deprive the wage-worker of the benefit of prospective wages, since nobody would lend on such security. ${ }^{20}$

${ }^{22}$ Supra, note 4. Also see note in 29 Mich. L. Rev. 915 (I93I).

${ }_{3}$ Citizens Loan Ass'n. v. B. \& M. R. R. Co., supra, note 2. And see note in 27 Ill. L. Rev. 60 ( 1932 ).

${ }_{4}$ Bridge v. Kedon, supra, note 4.

${ }^{25}$ See I Remington, Bankruptcy (2nd ed.), $387, \S 45 \mathrm{I}$.

${ }^{16}$ In re Voorhees, supra, note 2.

${ }^{7}$ Harris v. Mills, 28 Ill. 44, 8x Am. Dec. 259 (r86r); McMillan v. McCormick, II 7 Ill. . 79, 7 N.E. 132 ( 1886 ). See 25 Cyc. I00I-2.

${ }^{18}$ I Williston, Contracts (1922), 769, $§ 414$. See also note in 21 Harv. L. Rev. 275 (1908).

${ }^{19}$ See note in 27 Ill. L. Rev. 60 (I932).

${ }^{20}$ Memorandum by Barnes, Dist. J., in unreported case of Matter of Custin, D.C., N.D. Ill., Case No. 52,720 (1933). 
The main argument of policy advanced by the courts is that the purpose of the Bankruptcy Act is to give the bankrupt a "new start in life," which he cannot obtain if his earnings are tied up..$^{2 x}$ On the other hand, it is also the clear policy of the act to preserve for the creditor the rights which the bankrupt has given him in his property, collateral to his personal obligation.

Probably the best reason for recognizing a lien is that it is what the parties thought they were creating. ${ }^{22}$ The purpose of the transaction was to give the creditor some assurance of payment other than the personal obligation of the debtor. ${ }^{23}$

The federal courts in Illinois have had to take account of the determined stand of the Illinois Supreme Court in recognizing wage assignments as liens on wages earned after bankruptcy. ${ }^{24}$ For a while there were different decisions by different judges in the District Court for the Northern District of Illinois. ${ }^{25}$ The Circuit Court of Appeals for the Seventh Circuit, however, has recently repudiated the rule of the Illinois Court and adopted that prevailing in the other federal courts. ${ }^{26}$

Fred Marshall Merrifield

\section{RECENT CASES}

Bills and Notes-Checks-Presentment for Payment-Negotiable Instruments Law-[Massachusetts].-Defendant drew a check dated Dec. gth in favor of plaintiff on a Boston bank and procured its certification before delivery. Plaintiff's attorney received the same in Boston and mailed it to the plaintiff on the roth. Plaintiff lived about 50 miles from Boston getting his mail only by making irregular trips to the local post office. On the I5th, plaintiff sent the check by messenger to a local bank for deposit and collection. Check was refused deposit because of the failure of the drawee bank on the morning of the ${ }_{5}$ th. Plaintiff brought suit against the defendant drawer. Held, decree dismissing the bill affirmed. Seager v. Daughines et al., I87 N.E. 94 (Mass. 1933).

Although a check is a bill of exchange drawn on a bank payable on demand, it is not intended to circulate as a promissory note. Mussey v. Eagle Bank, 9 Metc. $3^{\text {I4 }}$ (Mass. I846); Gordon v. Levine, I94 Mass. 4I8, 80 N.E. 505 (I907). At the expiration of a reasonable time after issue, the risk of the drawee bank's solvency terminates as to the

${ }^{2 x}$ See particularly, In re Home Discount Co., supra, note 2.

22 In re Lind, supra, note 4.

${ }^{23}$ Note, II Boston L. Rev. 126 (1931).

${ }^{24}$ Mallin v. Wenham, and other cases cited supra, note 2.

${ }_{25}$ Injunctions were refused by Barnes, Dist. J., in Matter of Jackson, Case No. 49,545 (March, 1932), and Matter of Custin, supra, note 20 (both cases unreported); an injunction was granted by Carpenter, Dist. J., in Matter of Skorcz, Case No. 50,215 (October, 1932) (unreported).

${ }^{66}$ In re Skorcz, 67 F. (2d) I 87 (C.C.A. 7 th, 1933); Matter of Hunt, C.C.A. 7 th, Case No. 4936 (Nov., I933). 